\title{
Noncovalent Protection for Direct Synthesis of $\alpha$-Amino- $\omega$-Hydroxyl Poly(ethylene oxide)
}

Ye Chen, $\uparrow$ Pengfei Zhang, $\uparrow$ Shan Liu, $\uparrow$ David Pahovnik, $\ddagger$ Ema Žagar, $\ddagger$ Junpeng Zhao $\uparrow \S^{*}$, and Guangzhao Zhang $\dagger$

$\uparrow$ Faculty of Materials Science and Engineering, South China University of Technology, Guangzhou 510640, China

\$ Department of Polymer Chemistry and Technology, National Institute of Chemistry, Hajdrihova 19, 1000 Ljubljana, Slovenia

$\S$ Guangdong Provincial Key Laboratory of Luminescence from Molecular Aggregates (South China University of Technology), Guangzhou 510640, China

*E-mail:msjpzhao@scut.edu.cn

\section{Table of Contents}

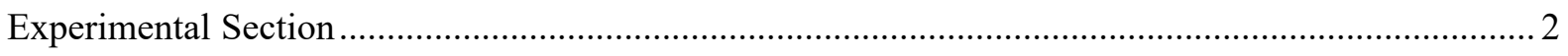

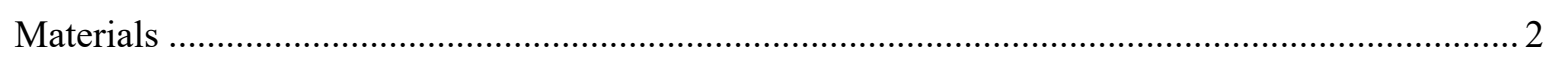

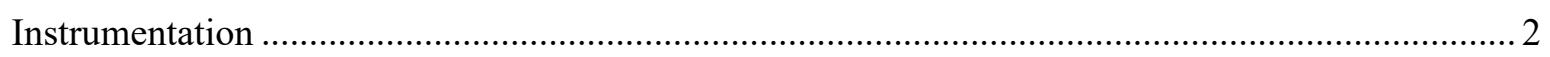

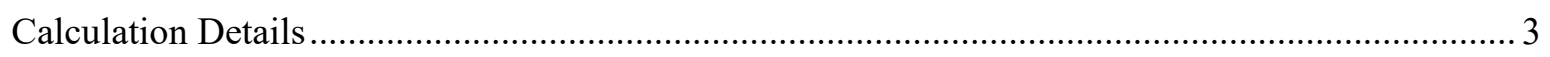

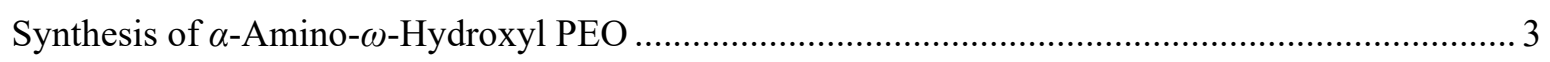

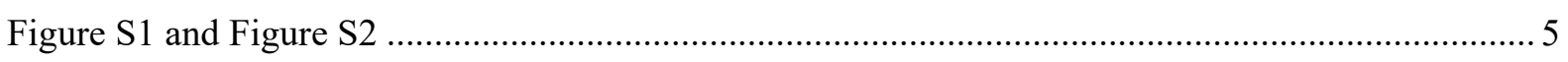

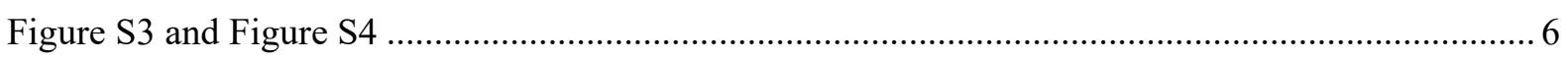

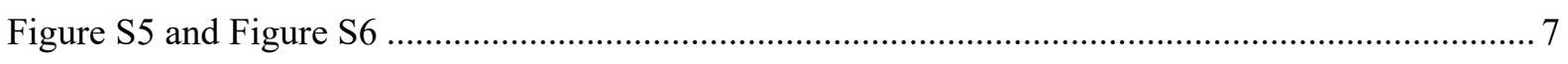

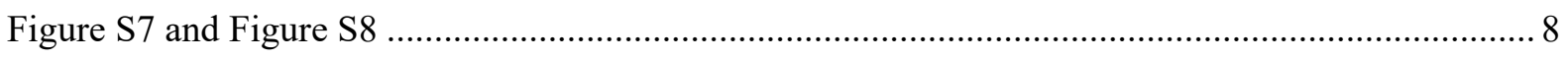

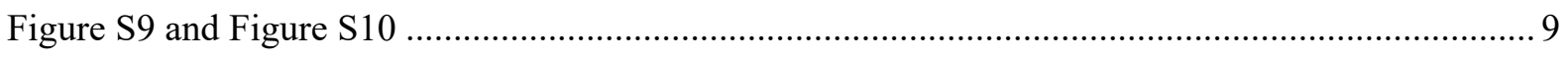

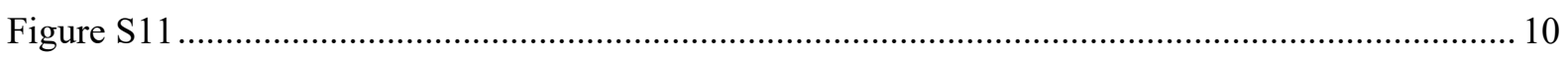

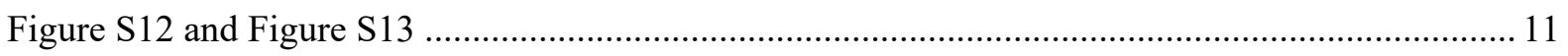

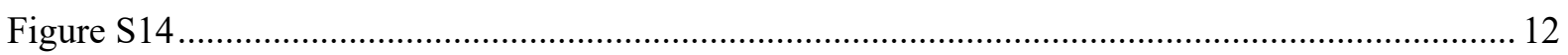

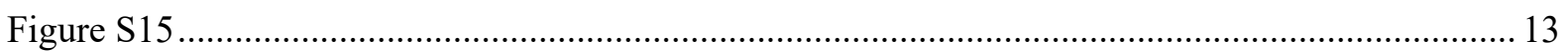

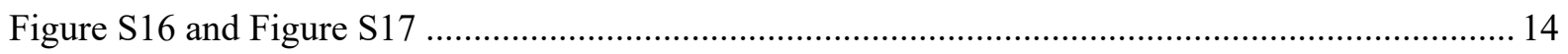

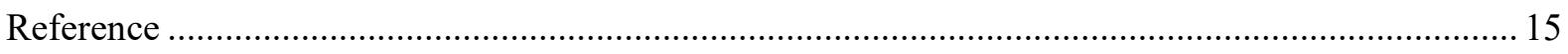

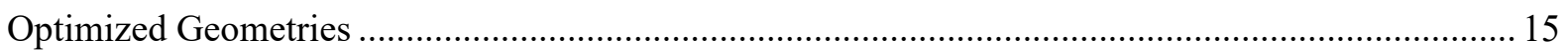




\section{Experimental Section}

\section{Materials}

Solvents including tetrahydrofuran (THF; AR), dichloromethane (DCM; AR), $n$-hexane (AR), and diethyl ether (AR) were purchased from Guangzhou Chemical Reagent. THF was dried successively over molecular sieve $(4 \AA)$ and calcium hydride $\left(\mathrm{CaH}_{2}\right)$ before distilled. Dichloromethane (DCM) and toluene were dried over $\mathrm{CaH}_{2}$ and distilled. 2-Aminoethanol (AE; 99\%), 6-amino-1-hexanol (AH; 97\%), 4-aminobenzyl alcohol (AB; 98\%), 2-amino-1,3propanediol (APD; 98\%), benzyl isothiocyanate (BITC; 98\%), and triethylborane (Et 3 B, $1.0 \mathrm{M}$ in THF) were purchased from TCI (Shanghai) and stored at $4{ }^{\circ} \mathrm{C}$ in a glovebox. 4(Aminomethyl)benzyl alcohol (AMB; 95\%) was purchased from Ark-Pharm and stored at $20{ }^{\circ} \mathrm{C}$ under argon. tert-Butylimino-tris(dimethylamino)phosphorane ( $\left.{ }^{t} \mathrm{BuP}_{1} ; 97 \%\right)$ and ethylene oxide (EO; 99.5\%) were purchased from Aldrich and stored at $4{ }^{\circ} \mathrm{C}$. AE was dried over $\mathrm{CaH}_{2}$ and vacuum-distilled. $\mathrm{AH}, \mathrm{AB}, \mathrm{APD}$, and $\mathrm{AMB}$ were dried on the vacuum line by azeotropic distillation of THF prior to use. Et $3 \mathrm{~B}$ was used as received. ${ }^{t} \mathrm{BuP}_{1}$ was dissolved in toluene into a $0.1 \mathrm{M}$ solution and used without purification. EO was condensed in a preevacuated Schlenk flask docked on the vacuum line and dried by stirring with sodium hydride in an ice-water bath for $4 \mathrm{~h}$, then cryo-distilled into a graduated cylindrical flask before finally cryo-distilled into the reaction flask.

\section{Instrumentation}

NMR spectra were recorded at $25^{\circ} \mathrm{C}$ on a Bruker Avance $3 \mathrm{HD} 600 \mathrm{NMR}$ spectrometer using deuterated dimethyl sulfoxide (DMSO- $d 6$ ) or toluene- $d 8$ as the solvent. ${ }^{1} \mathrm{H}$ NMR spectra were used to calculate number-average molar mass $\left(M_{\mathrm{n}, \mathrm{NMR}}\right)$ of the obtained poly(ethylene oxide) (PEO) by comparing the integrals of characteristic signals of the initiator-derived $\alpha$-end group and the methylenes of PEO main bodies. 
Size exclusion chromatography (SEC) was conducted in THF containing 5 vol. $\%$ triethylamine at $35{ }^{\circ} \mathrm{C}$ and a flow rate of $1.0 \mathrm{~mL} \mathrm{~min}{ }^{-1}$ using two identical PLgel MIXED-C columns. A series of narrowly dispersed PEO standards were used for calibration to obtain number-average molar mass $\left(M_{\mathrm{n}, \mathrm{SEC}}\right)$ and molar mass distribution ( $\bigoplus_{\mathrm{M}}$, polydispersity) of the synthesized PEOs. Matrix-assisted laser desorption/ionization time of flight mass spectrometry (MALDI-TOF MS) measurements were performed on a Bruker Autoflex III Smartbeam MALDI-TOF mass spectrometer (Bruker, Germany). The polymer sample and cationization agent (sodium trifluoroacetate) were dissolved in THF $\left(10 \mathrm{mg} \mathrm{mL}^{-1}\right)$. The matrix (dithranol) was also dissolved in THF $\left(20 \mathrm{mg} \mathrm{mL}^{-1}\right)$. Solutions of matrix, polymer, and cationization agent were mixed in a volume ratio of $20 / 5 / 1$. The mixed solution was spotted $(0.4 \mu \mathrm{L})$ on the MALDI sample plate and air-dried. Calibration was done externally with poly(methyl methacrylate) standards using the nearest neighbor positions.

\section{Calculation Details}

DFT calculations were performed by Gaussian 16 package. ${ }^{1}$ Geometry optimization and frequency calculations were conducted at B3LYP/6-31+G(d) level of theory coupled with DFT-D3 dispersion correction and SMD solvent model (THF). Energies were refined by single point energy calculation at M06-2X/6-311+G(d,p) level with DFT-D3 correction and SMD solvent model (THF). All transition state structures were confirmed by IRC. The energy unit is $\mathrm{kcal} \mathrm{mol}^{-1}$ unless stated otherwise.

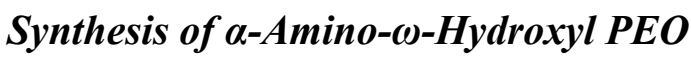

Polymerization of EO initiated by noncovalently protected AE. A typical procedure is given as

follows $\left(\mathrm{AE}^{2 \mathrm{~K}}\right.$ in Table 1). A reaction flask was dried with a heat gun on a vacuum line and transferred in a glovebox. $\mathrm{AE}(79 \mu \mathrm{L}, 1.32 \mathrm{mmol})$ and ${ }^{t} \mathrm{BuP}_{1}$ solution $(66 \mu \mathrm{L}, 6.6 \mu \mathrm{mol})$ were first loaded, followed by slow addition of Et 3 B solution $(1.58 \mathrm{~mL}, 1.58 \mathrm{mmol})$ upon stirring. 
The reaction flask was then docked back on the vacuum line, and EO (3.0 mL, $59.33 \mathrm{mmol})$ was introduced by cryo-distillation at $0{ }^{\circ} \mathrm{C}\left([\mathrm{EO}]_{0}=12.6 \mathrm{M}\right)$. The ice-water bath was removed in $30 \mathrm{~min}$, and the reaction mixture was stirring for another $2.5 \mathrm{~h}$ at room temperature (RT, $c a$. $25^{\circ} \mathrm{C}$ ) until a large amount of white solid (crystallized PEO) appeared and the magnetic stirrer stopped spinning. The product was dissolved in THF, reprecipitated in cold diethyl ether three times, collected by filtration, dried in a vacuum oven at RT, and stored at $-20^{\circ} \mathrm{C}$. The agreement between $M_{\mathrm{n}, \mathrm{SEC}}$ and theoretical number-average molar mass $\left(M_{\mathrm{n}, \mathrm{th}}\right)$ calculated from feed ratio of EO and AE confirmed complete consumption of EO. $M_{\mathrm{n}, \mathrm{th}}=2.0 \mathrm{~kg} \mathrm{~mol}^{-1} \cdot M_{\mathrm{n}, \mathrm{SEC}}$ (THF, PEO standards $)=2.6 \mathrm{~kg} \mathrm{~mol}^{-1}, \bigoplus_{\mathrm{M}}=1.05 .{ }^{1} \mathrm{H}$ NMR $\left(600 \mathrm{MHz}, \mathrm{DMSO}-d_{6}\right): \delta / \mathrm{ppm}=4.73-4.40$ $\left(-\mathrm{CH}_{2} \mathrm{CH}_{2} \mathrm{OH}\right), \quad 3.59-3.43 \quad\left(-\mathrm{OCH}_{2} \mathrm{CH}_{2} \mathrm{O}-\right), \quad 3.42-3.40 \quad\left(-\mathrm{OCH}_{2} \mathrm{CH}_{2} \mathrm{OH}\right), \quad 3.37-3.35$ $\left(\mathrm{H}_{2} \mathrm{NCH}_{2} \mathrm{CH}_{2} \mathrm{O}^{-}\right), 2.70-2.63\left(\mathrm{H}_{2} \mathrm{NCH}_{2} \mathrm{CH}_{2} \mathrm{O}^{-}\right) . M_{\mathrm{n}, \mathrm{NMR}}=2.6 \mathrm{~kg} \mathrm{~mol}^{-1}$.

Postmodification of $\alpha$-amino- $\omega$-hydroxyl PEO with BITC. $\mathrm{AE}^{2 \mathrm{~K}}(0.8 \mathrm{~g}, 0.31 \mathrm{mmol})$ was dissolved in DCM (8.0 mL), followed by addition of BITC (49 $\mu \mathrm{L}, 0.37 \mathrm{mmol})$. The reaction mixture was magnetically stirred at RT for $12 \mathrm{~h}$, then transferred to a $4{ }^{\circ} \mathrm{C}$ refrigerator. In another $12 \mathrm{~h}$, the precipitated white solid was collected by filtration and vacuum dried. $M_{\mathrm{n}, \mathrm{SEC}}(\mathrm{THF}, \mathrm{PEO}$ standards $)=2.6 \mathrm{~kg} \mathrm{~mol}^{-1}, \bigoplus_{\mathrm{M}}=1.05 .{ }^{1} \mathrm{H}$ NMR $\left(600 \mathrm{MHz}, \mathrm{DMSO}-d_{6}\right): \delta / \mathrm{ppm}$ $=\quad 8.05-7.77\left(\mathrm{C}_{6} \mathrm{H}_{5} \mathrm{CH}_{2} \mathrm{NHCSNH}^{-}\right), \quad 7.56-7.43 \quad\left(\mathrm{C}_{6} \mathrm{H}_{5} \mathrm{CH}_{2} \mathrm{NHCSNH}^{-}\right), \quad$ 7.35-7.20 $\left(\mathrm{C}_{6} \mathrm{H}_{5} \mathrm{CH}_{2} \mathrm{NHCSNH}-\right), 4.79-4.59\left(\mathrm{C}_{6} \mathrm{H}_{5} \mathrm{CH}_{2} \mathrm{NHCSNH}^{-}\right), 4.59-4.52\left(-\mathrm{CH}_{2} \mathrm{CH}_{2} \mathrm{OH}\right), 3.60-3.43$ $\left(-\mathrm{CH}_{2} \mathrm{CH}_{2} \mathrm{O}-\right), 3.43-3.40\left(-\mathrm{CH}_{2} \mathrm{CH}_{2} \mathrm{OH}\right) \cdot M_{\mathrm{n}, \mathrm{NMR}}=2.8 \mathrm{~kg} \mathrm{~mol}^{-1}$. 
(a)

(b)<smiles>C[C+](C)OCC(C)(C)OCCN</smiles>

$M_{\mathrm{n}, \mathrm{SEC}}=0.1 \mathrm{~kg} \mathrm{~mol}^{-1}$

$\bigoplus_{\mathrm{M}}=1.66$

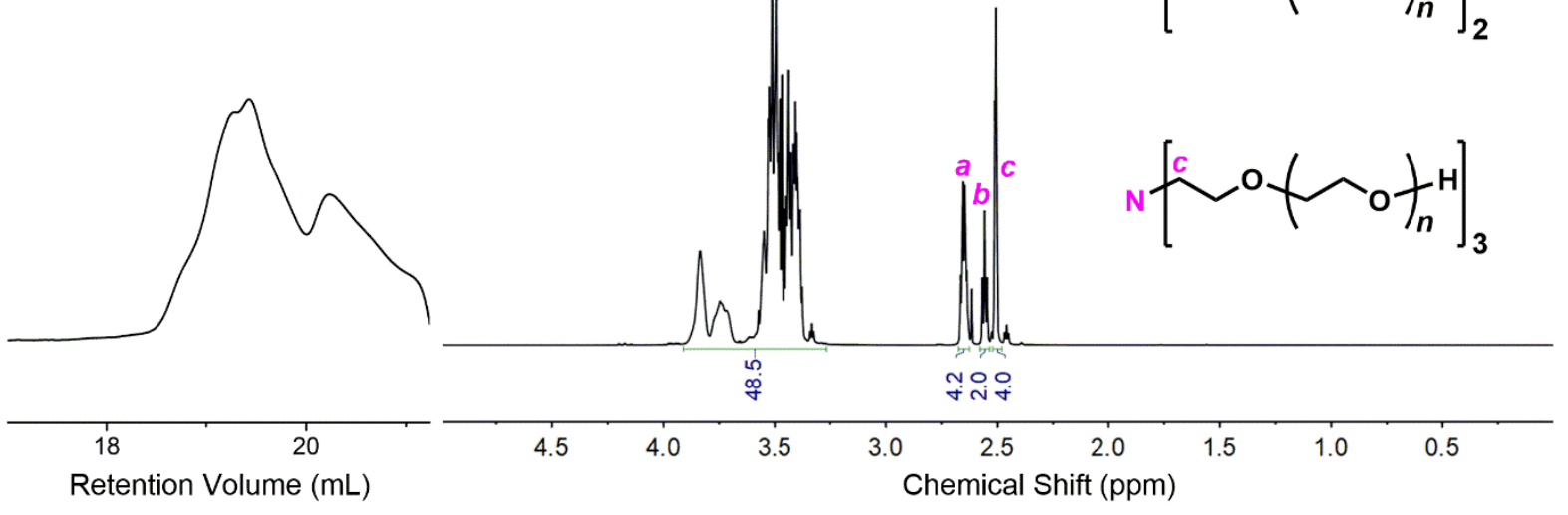

Figure S1. SEC trace (a; RI signal, THF, $35{ }^{\circ} \mathrm{C}$, PEO standards) and ${ }^{1} \mathrm{H}$ NMR spectrum (b; in DMSO- $d_{6}$ ) of the product obtained from the reaction between AE and EO in bulk at RT with no catalyst added ( $\mathrm{AE}^{\mathrm{Ct} 1}$ in Table 1$)$.
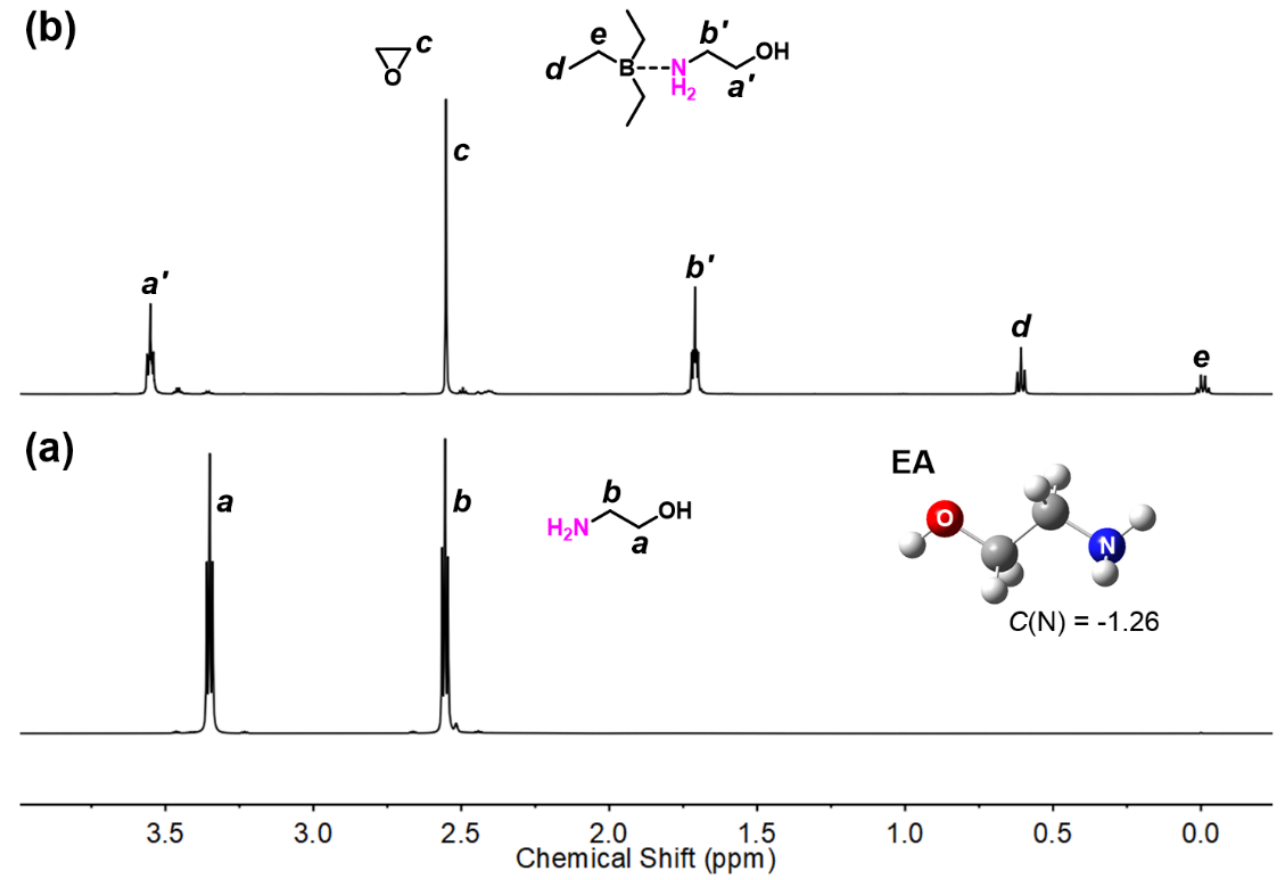

Figure S2. (a) ${ }^{1} \mathrm{H}$ NMR spectrum of AE (in DMSO- $d_{6}$ ) and its $3 \mathrm{D}$ structure given by DFT calculation with ESP charge noted. (b) ${ }^{1} \mathrm{H}$ NMR spectrum of a mixture of $\mathrm{AE}, \mathrm{Et}_{3} \mathrm{~B}$, and EO $\left(\right.$ molar ratio $=1 / 1 / 10$, mixing time $=24 \mathrm{~h} ; \mathrm{AE}^{\mathrm{Ct} 2}$ in Table 1$)$. 


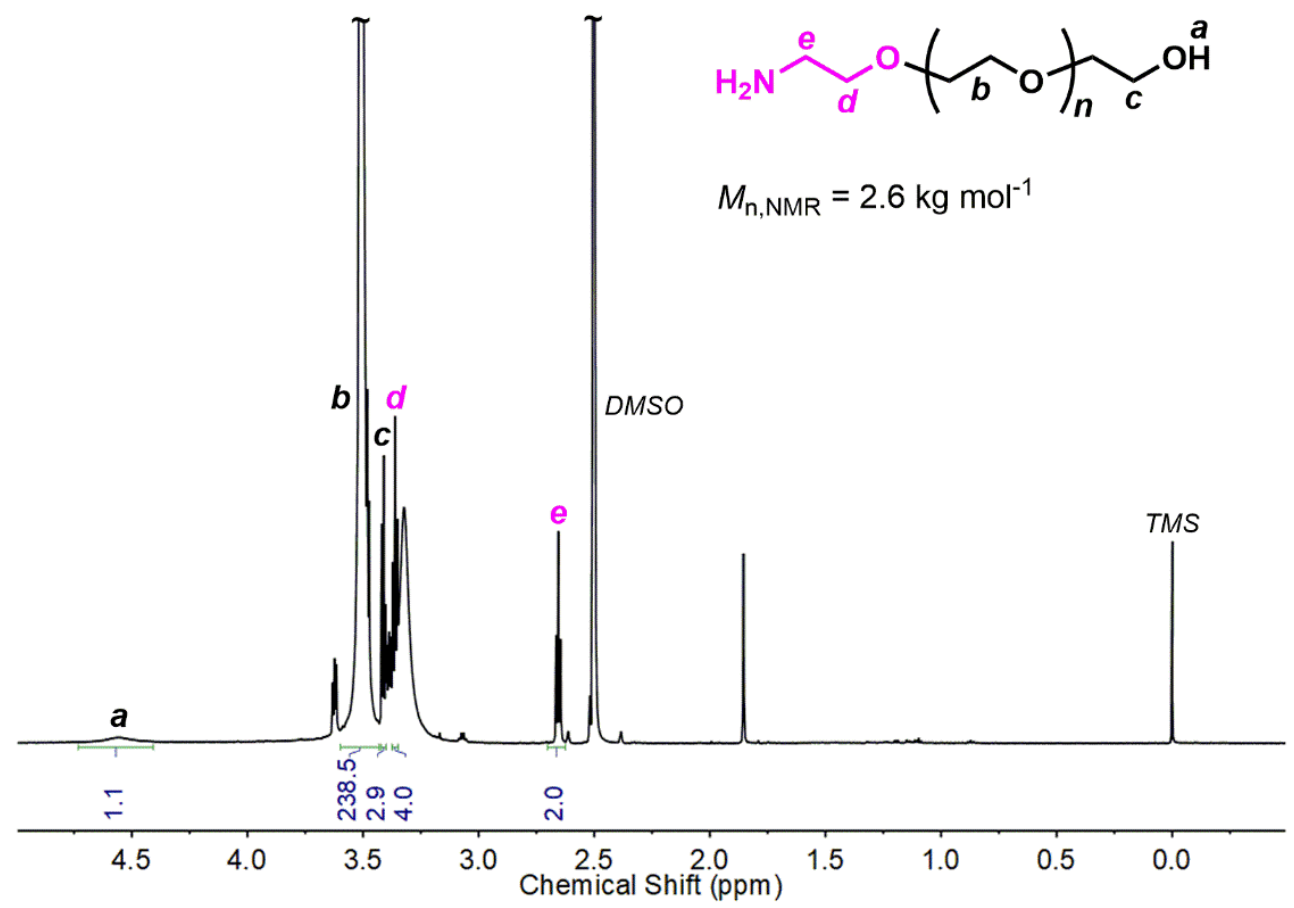

Figure S3. ${ }^{1} \mathrm{H}$ NMR spectrum (in DMSO- $d_{6}$ ) of the isolated product of $\mathrm{AE}^{2 \mathrm{~K}}$ (Table 1 and Figure 1) with signal integrals noted.

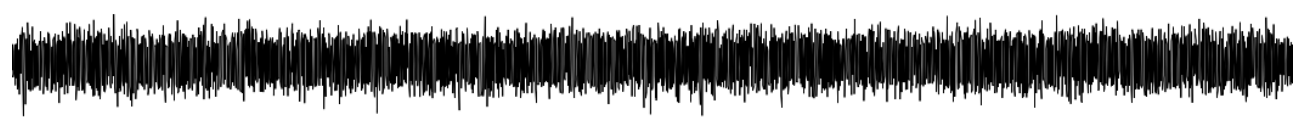

\begin{tabular}{lllllll}
\hline 80 & 60 & 40 & 20 & 10 & 1 \\
Chemical Shift & $(\mathrm{ppm})$ & -20 & -40 & -60 & -80
\end{tabular}

Figure S4. ${ }^{11} \mathrm{~B}$ NMR spectrum (in DMSO-d6) of the product of $\mathrm{AE}^{2 \mathrm{~K}}$ (Table 1) reprecipitated in diethyl ether (three times). 


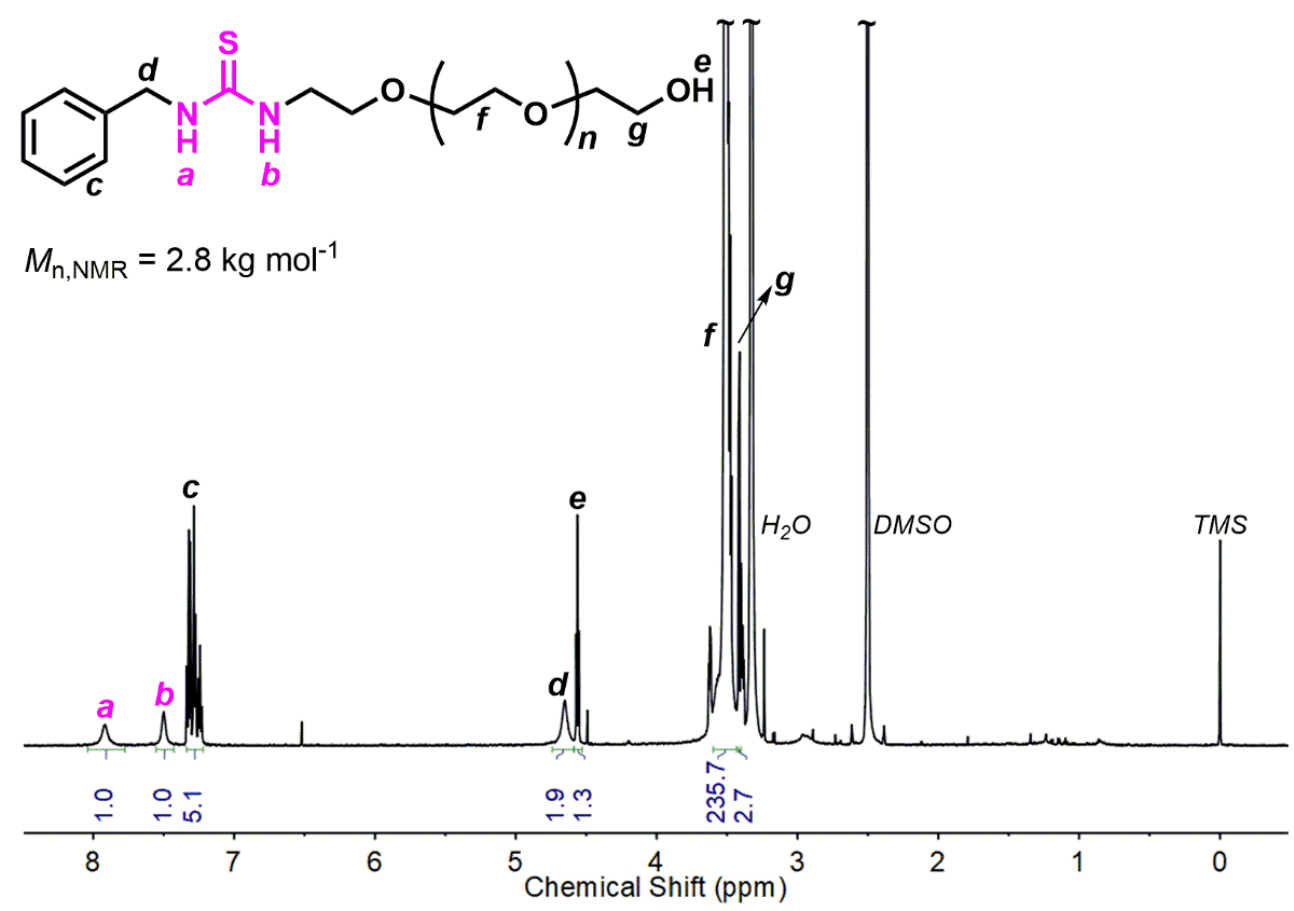

Figure S5. ${ }^{1} \mathrm{H}$ NMR spectrum (in DMSO- $d_{6}$, with signal integrals noted) of the $\alpha$ benzylthiourea- $\omega$-hydroxyl PEO obtained from postmodification of the product of $\mathrm{AE}^{2 \mathrm{~K}}$ with BITC.

(a)

(b)

$5.1 \mathrm{~kg} \mathrm{~mol}^{-1}$

$E_{\mathrm{M}}=1.04$
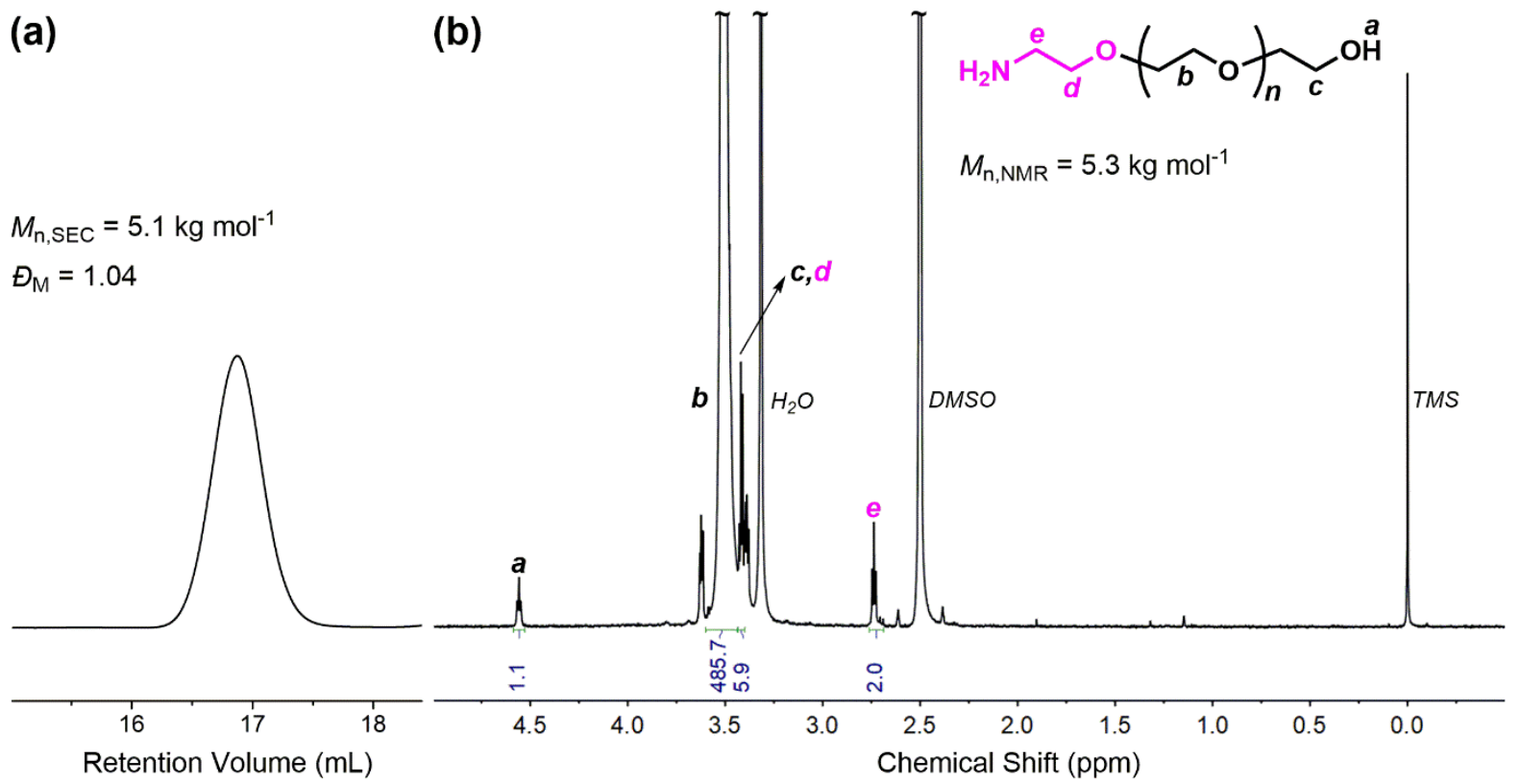

Figure S6. SEC trace (a; THF, $35{ }^{\circ} \mathrm{C}$, PEO standards) and ${ }^{1} \mathrm{H}$ NMR spectrum (b; in DMSO$d_{6}$, with signal integrals noted) of the isolated product of $\mathrm{AE}^{5 \mathrm{~K}}$ (Table 1). 
(a)

$M_{\mathrm{n}, \mathrm{SEC}}=10.3 \mathrm{~kg} \mathrm{~mol}^{-1}$

$\bigoplus_{\mathrm{M}}=1.06$ (b)

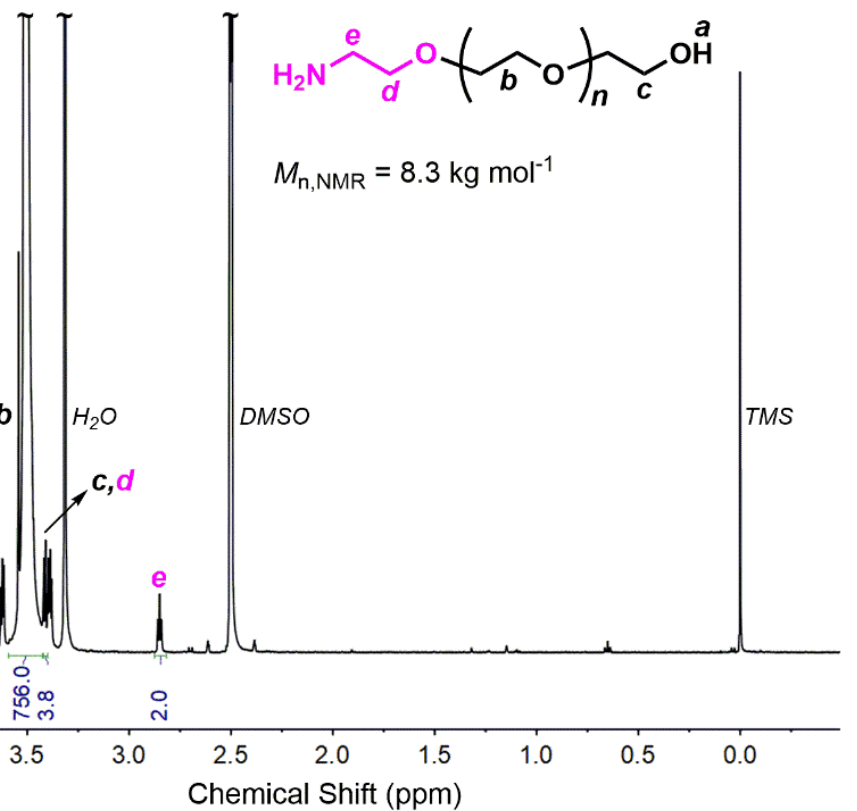

Figure S7. SEC trace (a; THF, $35{ }^{\circ} \mathrm{C}$, PEO standards) and ${ }^{1} \mathrm{H}$ NMR spectrum (b; in DMSO$d 6$, with signal integrals noted) of the isolated product of $\mathrm{AE}^{8 \mathrm{~K}}$ (Table 1).

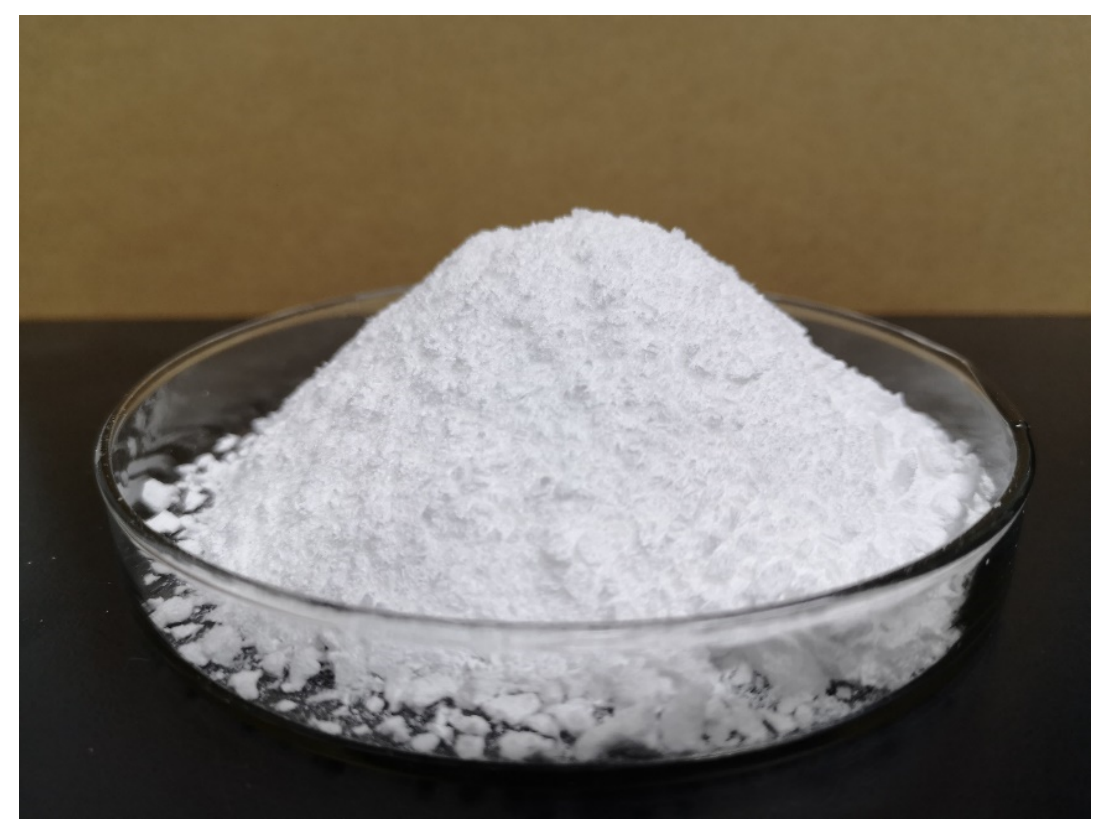

Figure S8. Photograph of $15 \mathrm{~g}$ of a one-step synthesized $\alpha$-amino- $\omega$-hydroxyl PEO with the molar mass of $c a .5 \mathrm{~kg} \mathrm{~mol}^{-1}\left(\mathrm{AE}^{5 \mathrm{~K}}\right.$ in Table 1$)$. 


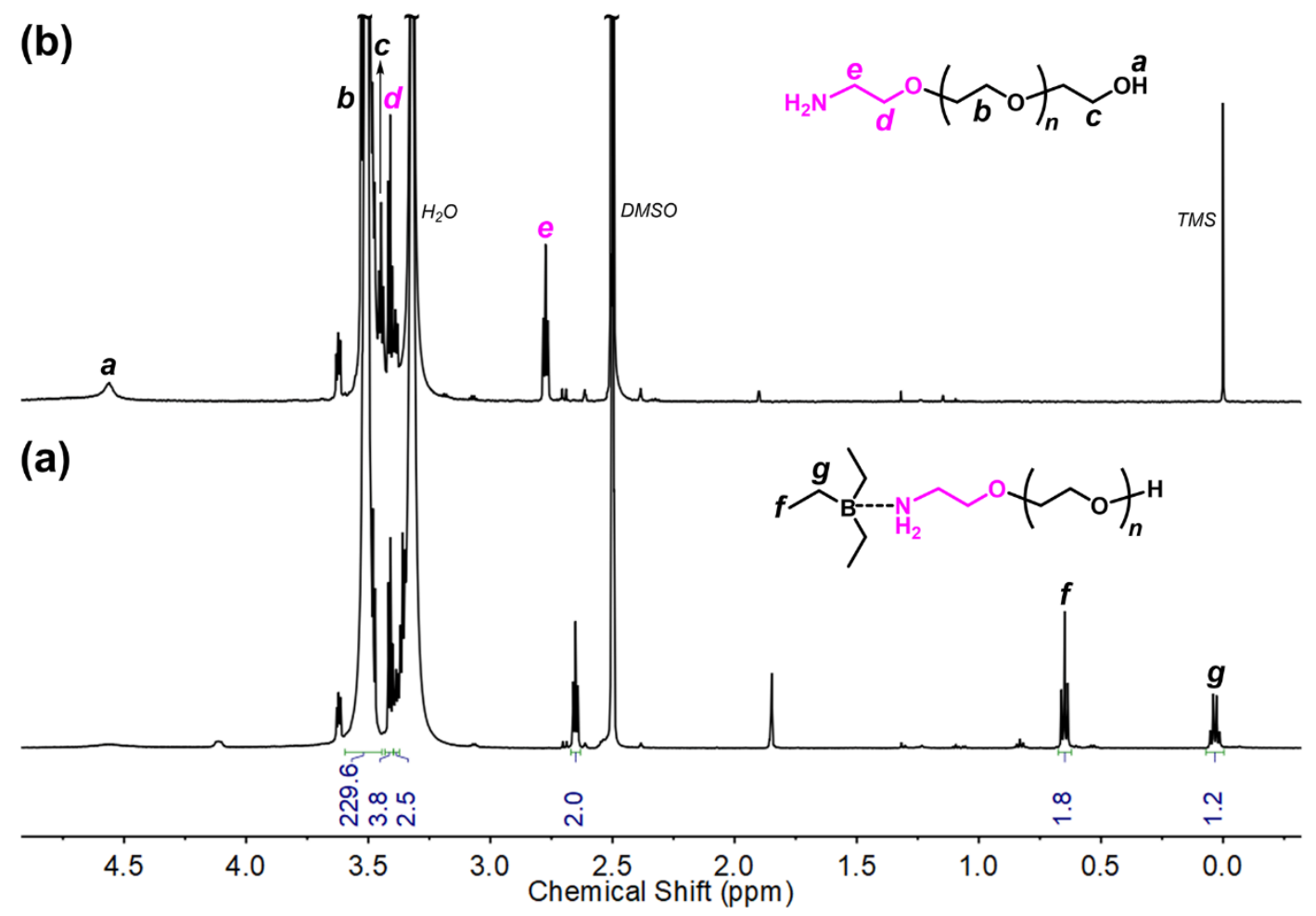

Figure S9. ${ }^{1} \mathrm{H}$ NMR spectra (in DMSO-d6) of the product of $\mathrm{AE}^{2 \mathrm{~K}}$ (Table 1) precipitated in $n$ hexane and stored in the open air at RT for 1 week (a) and subsequently reprecipitated in diethyl ether before measurement (b), corresponding to the MALDI-TOF MS spectra in Figure 3b.

(a)

$M_{\mathrm{n}, \mathrm{SEC}}=2.9 \mathrm{~kg} \mathrm{~mol}^{-1}$

$\oplus_{M}=1.06$ (b)

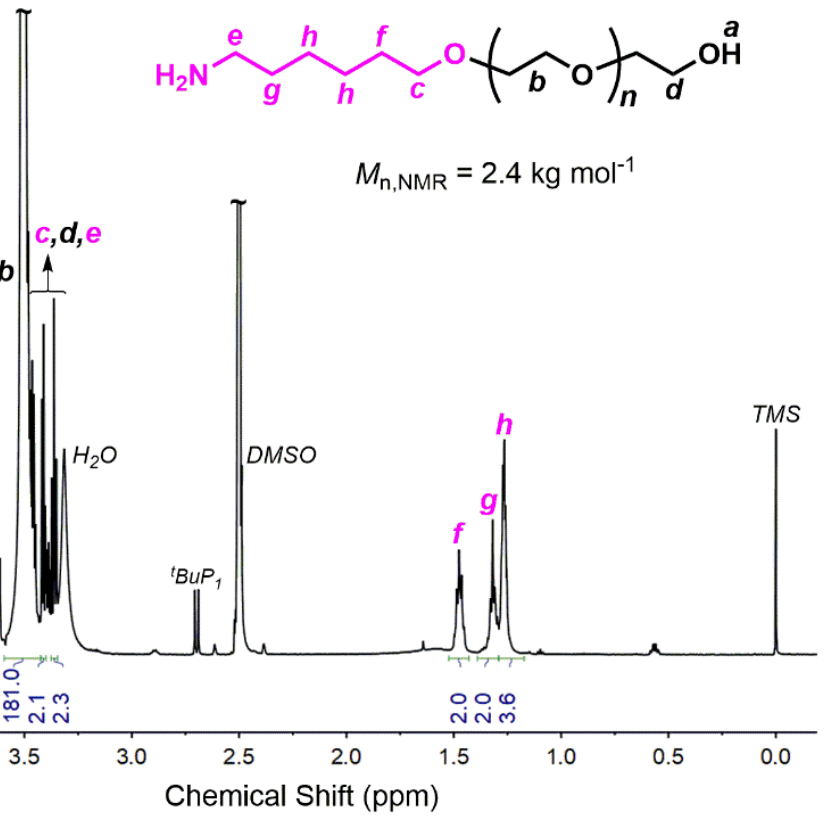

Figure S10. SEC trace (a; THF, $35{ }^{\circ} \mathrm{C}$, PEO standards) and ${ }^{1} \mathrm{H}$ NMR spectrum (b; in DMSO$d_{6}$, with signal integrals noted) of the isolated product of $\mathrm{AH}^{2 \mathrm{~K}}$ (Table 1). 
(a)

(b)

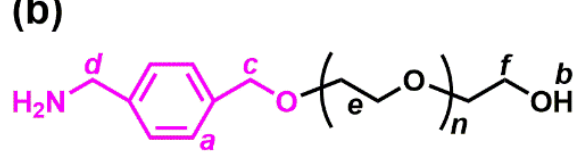

$M_{\mathrm{n}, \mathrm{SEC}}=4.0 \mathrm{~kg} \mathrm{~mol}^{-1}$

$M_{\mathrm{n}, \mathrm{NMR}}=3.4 \mathrm{~kg} \mathrm{~mol}^{-1}$

$\bigoplus_{\mathrm{M}}=1.09$

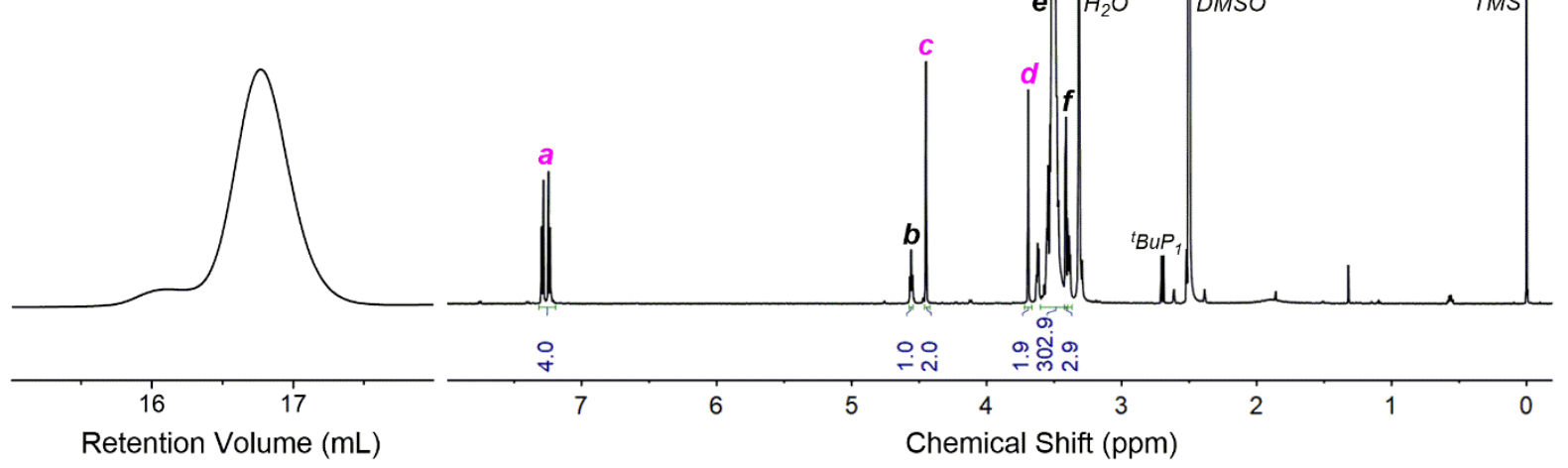

Figure S11. SEC trace (a; THF, $35{ }^{\circ} \mathrm{C}$, PEO standards) and ${ }^{1} \mathrm{H}$ NMR spectrum (b; in DMSO$d_{6}$, with signal integrals noted) of the isolated product of $\mathrm{AMB}^{3 \mathrm{~K}}$ (Table 1).

$Ð_{M}$ of this sample (also $A E^{8 K}$ ) is obtained with the shoulder of the SEC peak incorporated. The shoulder, which represents the existence of a double-molar-mass byproduct, may most likely be generated by initiation of the ROP from adventitious water (the amino alcohols are highly hygroscopic) and/or impurities (e.g. diols) in the amino alcohol (the labeled purity of AMB is 95\%, and the impurities most likely include 1,4-benzenedimethanol since ABM is a monoamination product of it).

A larger amount of THF is needed for the dissolution of $A H$ and $A M B$, so EO concentration is lower in these two cases and more ${ }^{t} \mathrm{Bu}_{1}$ is added accordingly to ensure complete consumption of EO in a reasonable time scale (Table 1). This has led to some residuals of ${ }^{t} \mathrm{Bu} \mathrm{P}_{1}$ in the ${ }^{1} \mathrm{H}$ $N M R$ spectra (Figure S1O and S11) since the products of $A H^{2 K}$ and $A M B^{3 K}$ are precipitated in diethyl ether only once. Nevertheless, this should not impede bio-related applications of the $P E O$ amines because 1) the residual of ${ }^{t} B u P_{1}$ can be removed by further reprecipitations of the $P E O$ amines when necessary (the first precipitation has already removed $>65 \%$ of ${ }^{t} B u P_{1}$ ), and 2) it was proven in our previous study that the residual of ${ }^{t} B u P_{1}$, even with much larger amounts, did not cause cytotoxicity to the PEO product. ${ }^{2}$ 
(a)

(b)<smiles>CC(C)COCCOC(C)COc1ccc(N)cc1</smiles>

$M_{\mathrm{n}, \mathrm{SEC}}=4.1 \mathrm{~kg} \mathrm{~mol}^{-1}$

$\bigoplus_{\mathrm{M}}=1.08$

$M_{\mathrm{n}, \mathrm{NMR}}=3.2 \mathrm{~kg} \mathrm{~mol}^{-1}$
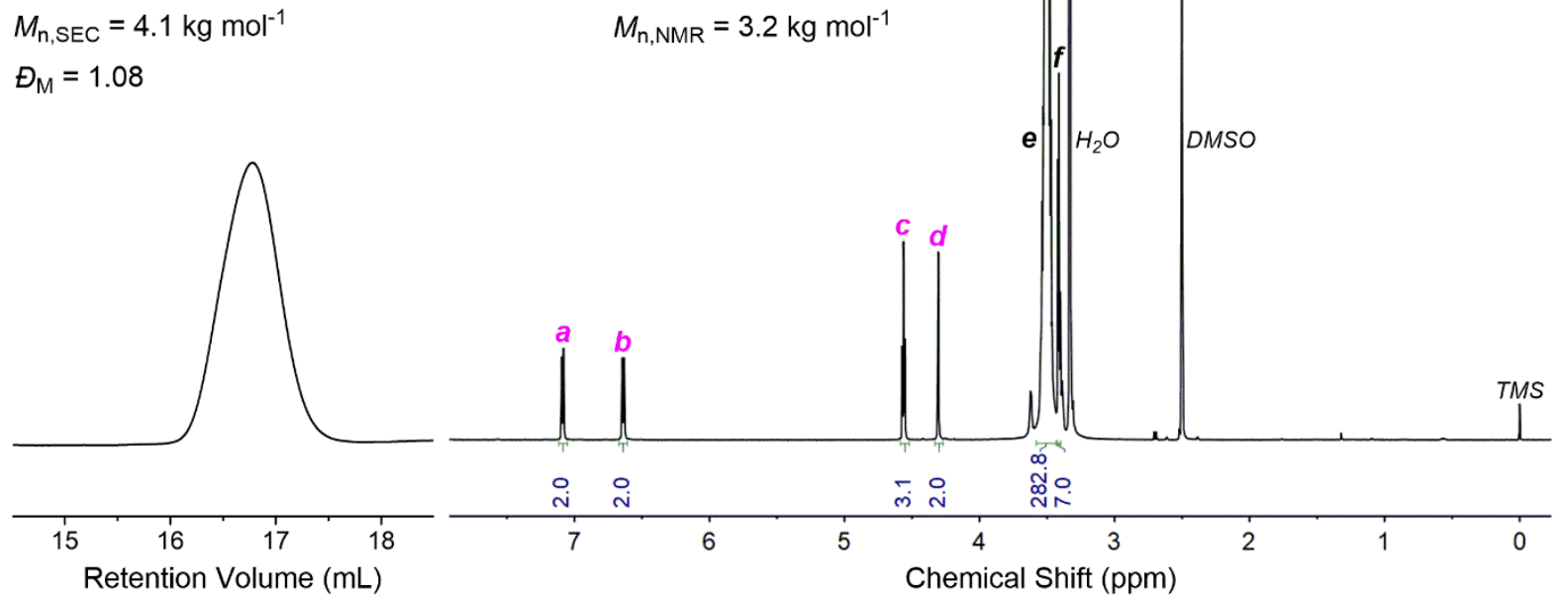

Figure S12. SEC trace (a; THF, $35^{\circ} \mathrm{C}$, PEO standards) and ${ }^{1} \mathrm{H}$ NMR spectrum (b; in DMSO$d_{6}$, with signal integrals noted) of the isolated product of $\mathrm{AB}^{3 \mathrm{~K}}$ (Table 1).
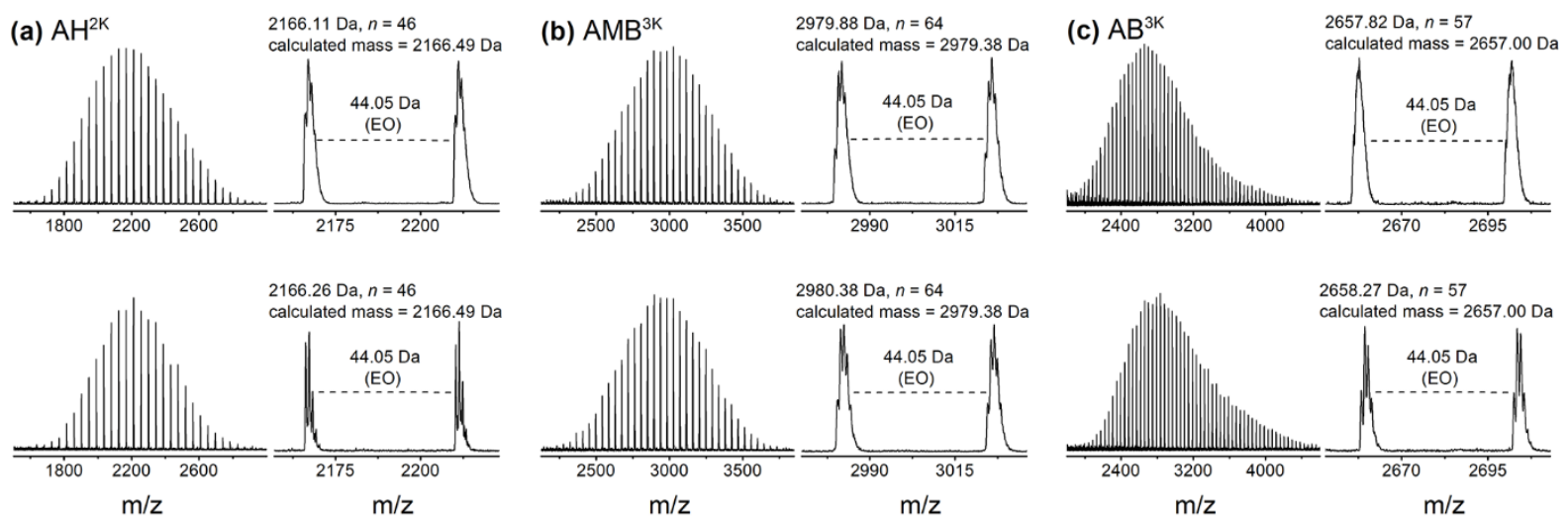

Figure S13. MALDI-TOF MS spectra of the isolated products of $\mathrm{AH}^{2 \mathrm{~K}}(\mathrm{a}), \mathrm{AMB}^{3 \mathrm{~K}}(\mathrm{~b})$, and $\mathrm{AB}^{3 \mathrm{~K}}$ (c) (Table 1) stored in the open air at RT for 1 day (upper figures) and 1 month (lower figures), respectively. 
(a)
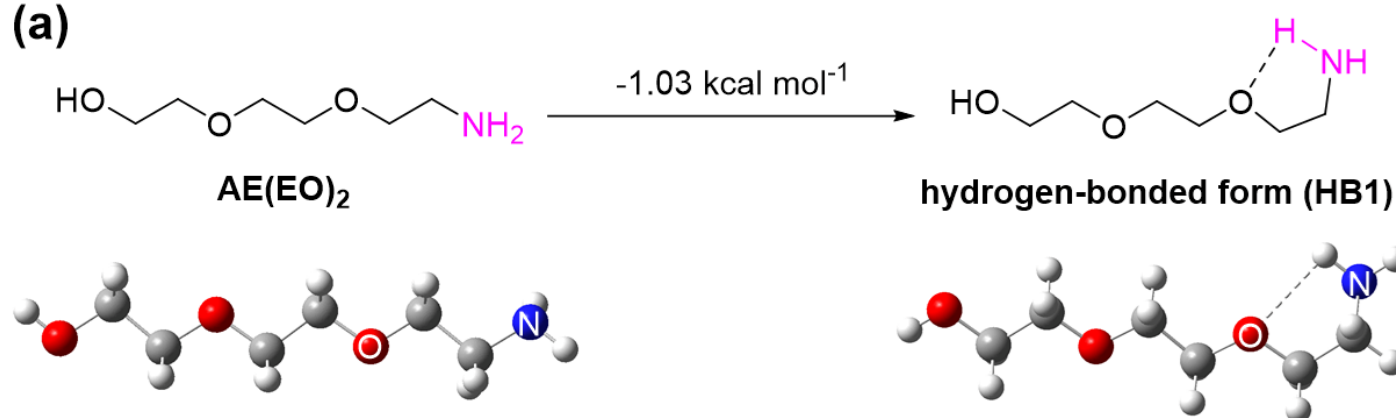

$C(\mathrm{O})=-0.78, \mathrm{C}\left(-\left(\mathrm{CH}_{2}\right)_{2} \mathrm{NH}_{2}\right)=0.46$

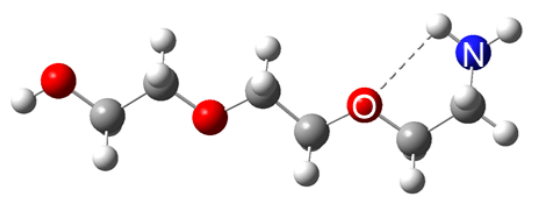

$C(\mathrm{O})=-0.55, \mathrm{C}\left(-\left(\mathrm{CH}_{2}\right)_{2} \mathrm{NH}_{2}\right)=0.23$

(b)

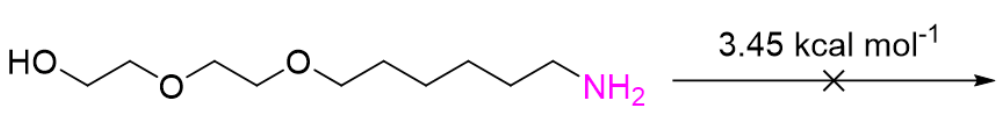

$\mathrm{AH}(\mathrm{EO})_{2}$

hydrogen-bonded form (HB2)
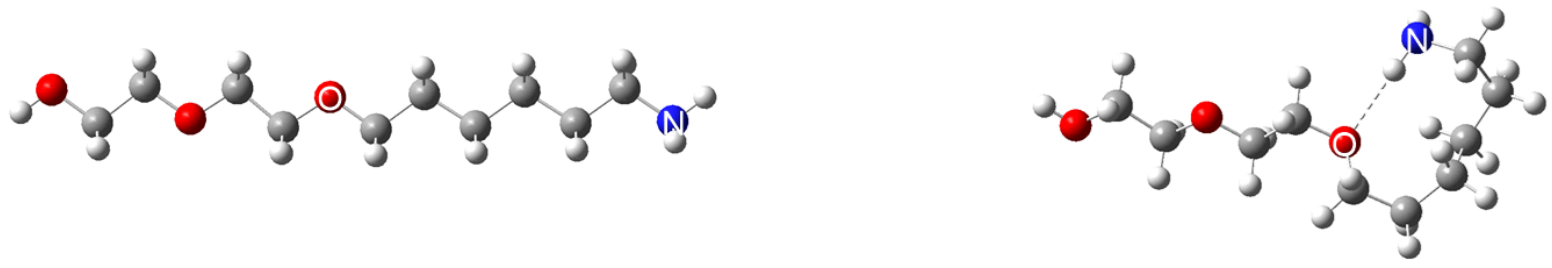

Figure S14. Relative energies and ESP charges obtained from DFT calculations of the chemical structures simulating the amino termini of $\alpha$-amino- $\omega$-hydroxyl PEOs synthesized with $\mathrm{AE} \mathrm{(a)} \mathrm{and} \mathrm{AH}(\mathrm{b})$ as the initiators, respectively. 

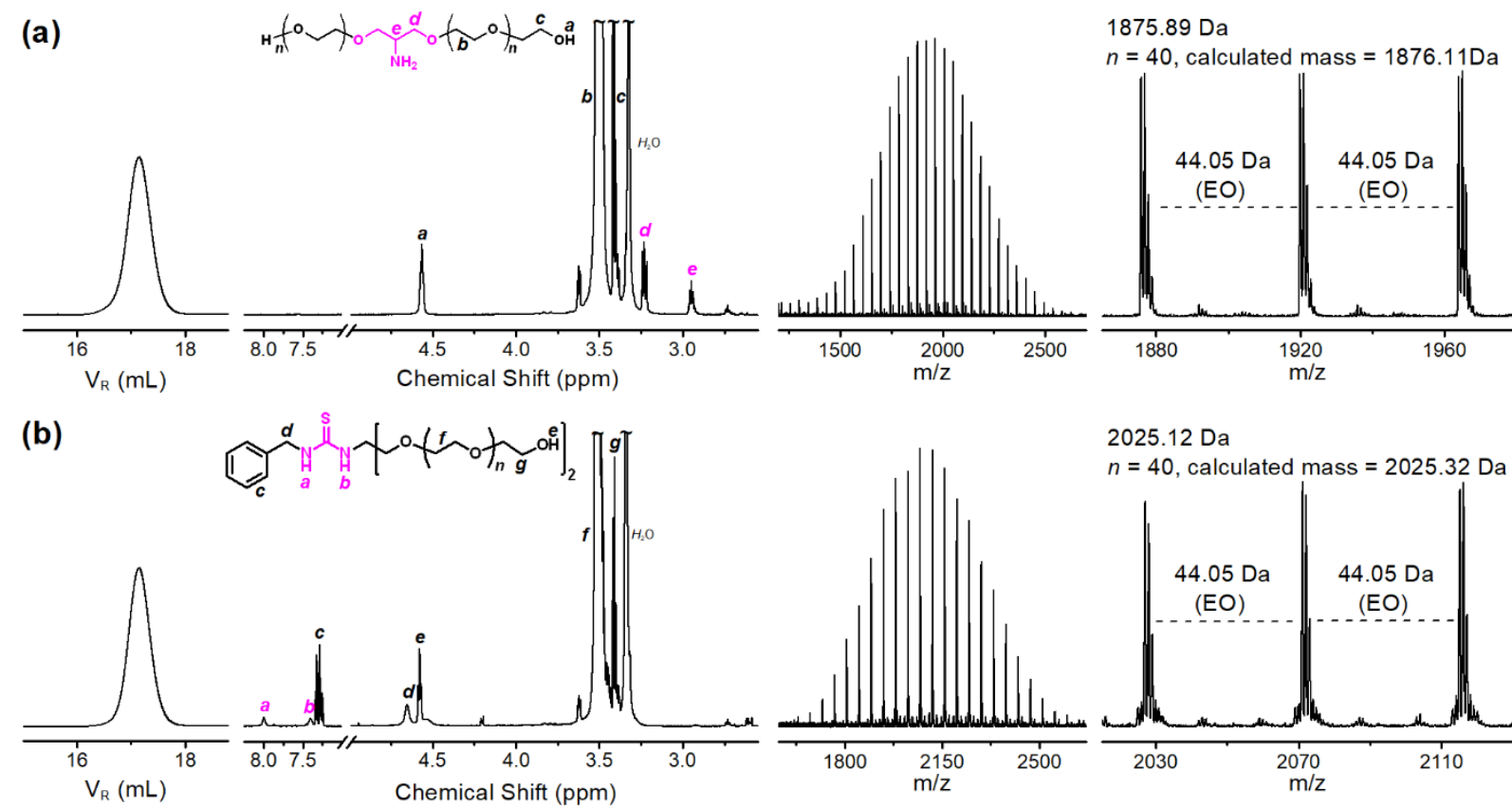

2025.12 Da

$n=40$, calculated mass $=2025.32 \mathrm{Da}$

Figure S15. SEC traces (left; THF, $35{ }^{\circ} \mathrm{C}$ ), ${ }^{1} \mathrm{H}$ NMR spectra (middle; in DMSO-d6), and MALDI-TOF MS spectra with magnified areas (right; reflective mode, ionized by Na cation) of the one-step synthesized trifunctional PEO bearing an amino group in the middle and a hydroxyl group at each end using APD as the initiator (isolated product of $\mathrm{APD}^{2 \mathrm{~K}}$ in Table 1) (a), and the product obtained from postmodification of the product of $\mathrm{APD}^{2 \mathrm{~K}}$ with BITC (b). 


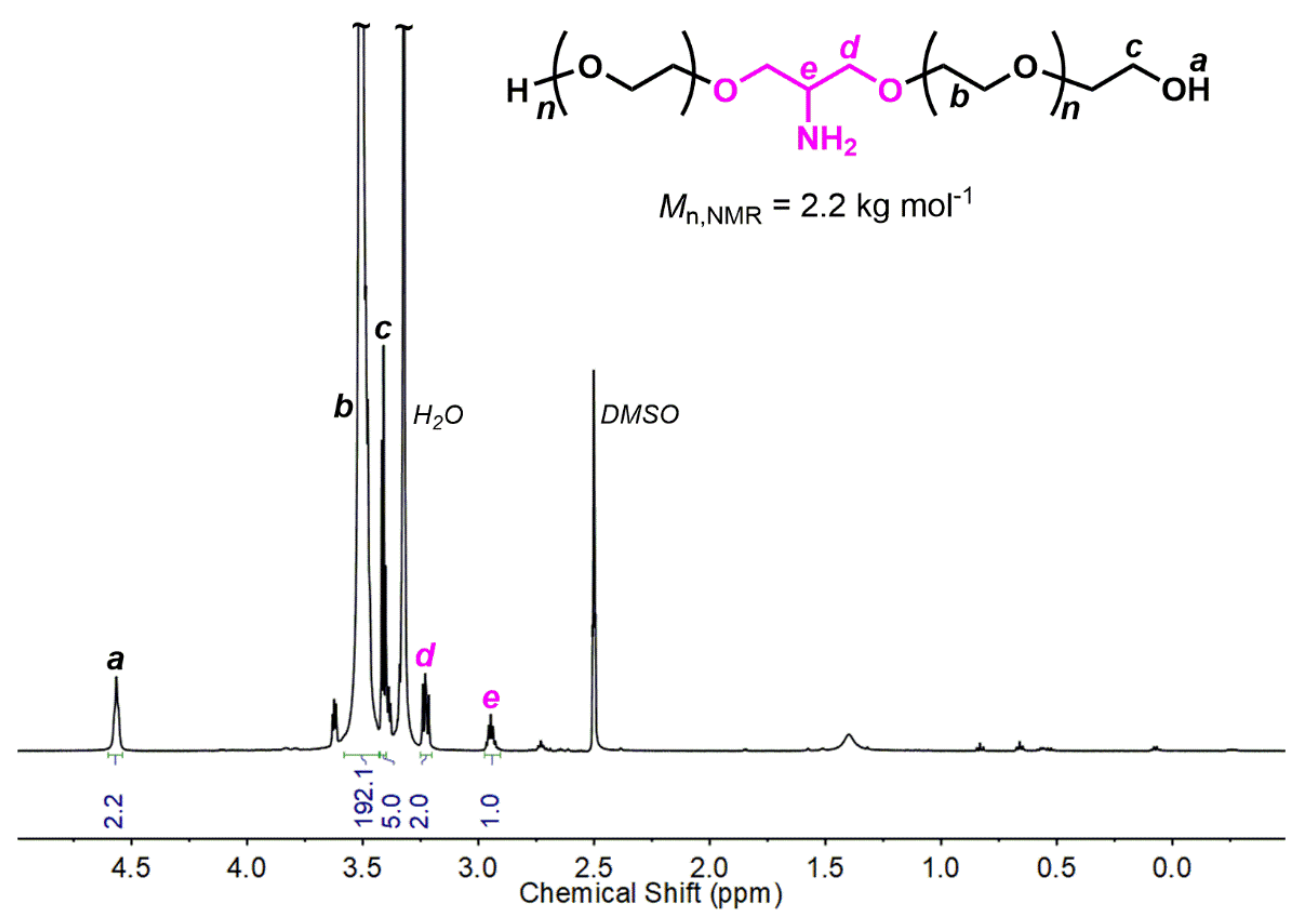

Figure S16. ${ }^{1} \mathrm{H}$ NMR spectrum (in DMSO- $d_{6}$, with signal integrals noted) of the isolated product of $\mathrm{APD}^{2 \mathrm{~K}}$ (Table 1).

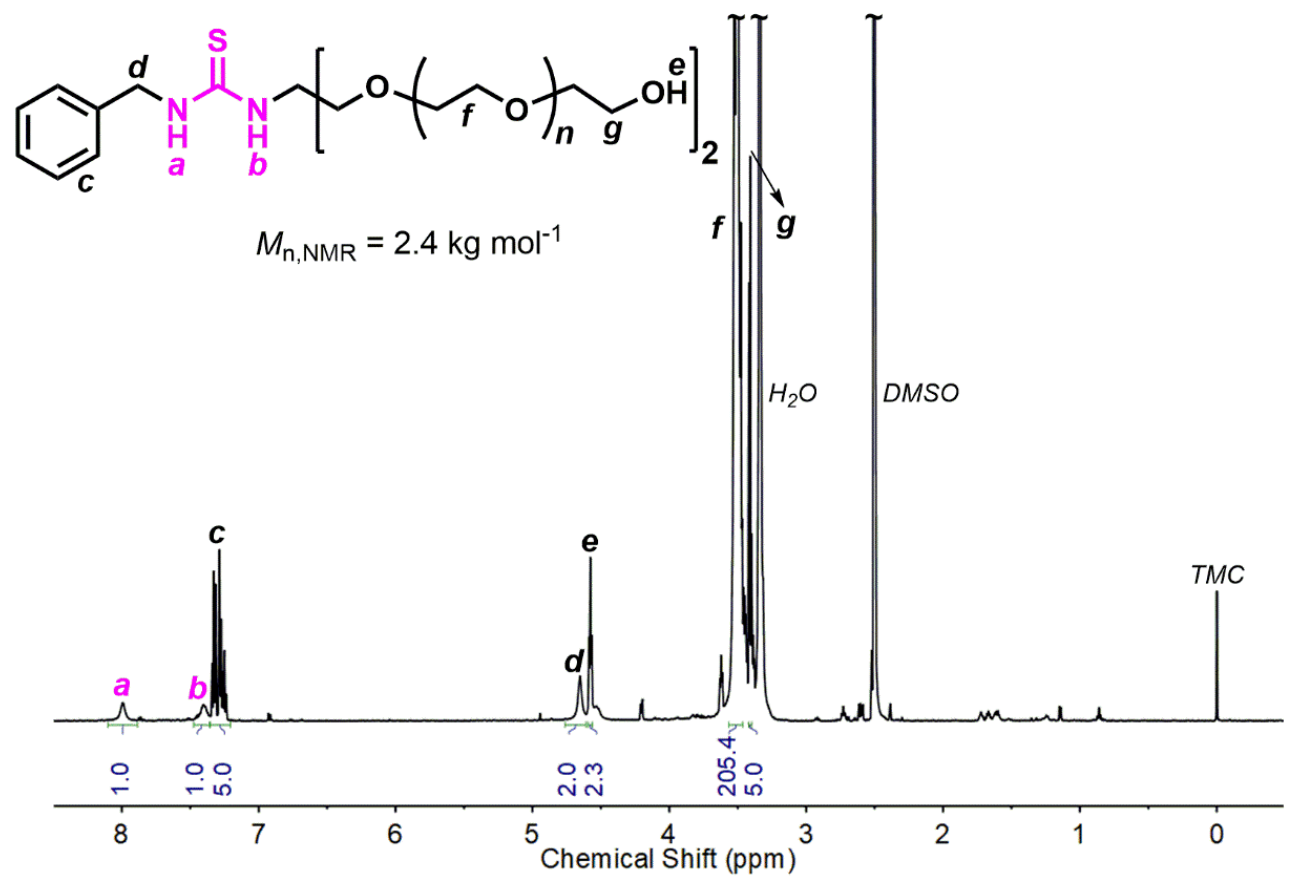

Figure S17. ${ }^{1} \mathrm{H}$ NMR spectrum (in DMSO- $d_{6}$, with signal integrals noted) of the isolated product obtained from postmodification of the product of $\mathrm{APD}^{2 \mathrm{~K}}$ with BITC. 


\section{Reference}

1. Frisch, M.; Trucks, G.; Schlegel, H.; Scuseria, G.; Robb, M.; Cheeseman, J.; Scalmani, G.; Barone, V.; Petersson, G.; Nakatsuji, H. Gaussian 16. Gaussian, Inc. Wallingford, CT: 2016.

2. Chen, Y.; Shen, J.; Liu, S.; Zhao, J.; Wang, Y.; Zhang, G. High Efficiency Organic Lewis Pair Catalyst for Ring-Opening Polymerization of Epoxides with Chemoselectivity. Macromolecules 2018, 51 (20), 8286-8297.

\section{Optimized Geometries}

TS1

$\begin{array}{crrr}\mathrm{C} & 1.72526600 & -0.36792700 & 0.45056900 \\ \mathrm{H} & 0.92906500 & -1.10848900 & 0.59579200 \\ \mathrm{H} & 1.97210800 & 0.07150400 & 1.42949300 \\ \mathrm{C} & 1.26881600 & 0.72420200 & -0.50587200 \\ \mathrm{H} & 0.91825400 & 0.27814200 & -1.44148200 \\ \mathrm{H} & 2.12282600 & 1.37502600 & -0.73875200 \\ \mathrm{O} & 2.88169500 & -0.97804000 & -0.13210400 \\ \mathrm{H} & 3.13992600 & -1.73459800 & 0.41936900 \\ \mathrm{~N} & 0.15431400 & 1.48933500 & 0.07744100 \\ \mathrm{H} & 0.44505600 & 1.97234900 & 0.92886100 \\ \mathrm{H} & -0.16848500 & 2.20142500 & -0.57622200 \\ \mathrm{C} & -1.55737400 & 0.36999600 & 0.49312000 \\ \mathrm{C} & -1.92444400 & -0.49992700 & -0.62961000 \\ \mathrm{O} & -2.98932800 & -0.86496900 & 0.18270700 \\ \mathrm{H} & -1.11969900 & -0.09054100 & 1.36800600 \\ \mathrm{H} & -1.20197800 & -1.30170600 & -0.86246500 \\ \mathrm{H} & -2.18946700 & 0.02866400 & -1.56316500 \\ \mathrm{H} & -2.14032800 & 1.26888100 & 0.64441100\end{array}$

TS2

$\begin{array}{lrrr}\mathrm{C} & 1.06397600 & -2.57988100 & -0.39828400 \\ \mathrm{H} & 0.19578000 & -3.04483800 & 0.08279500 \\ \mathrm{H} & 1.41300300 & -3.23560100 & -1.20747500\end{array}$




\begin{tabular}{|c|c|c|c|}
\hline $\mathrm{C}$ & 0.69407400 & -1.22239600 & -0.96782800 \\
\hline $\mathrm{H}$ & 1.56773400 & -0.82789000 & -1.50789300 \\
\hline $\mathrm{H}$ & -0.08304600 & -1.37681400 & -1.72032700 \\
\hline $\mathrm{O}$ & 2.11651300 & -2.39020000 & 0.57053500 \\
\hline $\mathrm{H}$ & 2.27186500 & -3.22825100 & 1.03558400 \\
\hline $\mathrm{N}$ & 0.22644000 & -0.26289400 & 0.04832500 \\
\hline $\mathrm{H}$ & 0.40522700 & -0.65568500 & 0.97103500 \\
\hline $\mathrm{H}$ & 0.95897100 & 1.13674100 & -0.21628500 \\
\hline B & -1.30727800 & 0.26730900 & 0.03670400 \\
\hline $\mathrm{C}$ & -1.54740500 & 1.34975500 & -1.17557100 \\
\hline $\mathrm{H}$ & -2.56689900 & 1.75591100 & -1.04929600 \\
\hline $\mathrm{H}$ & -0.88253500 & 2.22129600 & -1.04587200 \\
\hline $\mathrm{C}$ & -2.31640000 & -1.04352600 & -0.14258200 \\
\hline $\mathrm{H}$ & -3.32497300 & -0.64949200 & -0.35843200 \\
\hline $\mathrm{H}$ & -2.04683400 & -1.63290900 & -1.03348800 \\
\hline $\mathrm{C}$ & -1.58710700 & 0.95472900 & 1.50949000 \\
\hline $\mathrm{H}$ & -2.68095900 & 1.02213300 & 1.64452000 \\
\hline $\mathrm{H}$ & -1.25187900 & 0.26866000 & 2.30924100 \\
\hline $\mathrm{C}$ & -1.40857100 & 0.87295900 & -2.63255500 \\
\hline $\mathrm{H}$ & -1.69639500 & 1.65055600 & -3.35684700 \\
\hline $\mathrm{H}$ & -0.37422300 & 0.59043500 & -2.87000100 \\
\hline $\mathrm{H}$ & -2.03840200 & -0.00378100 & -2.83715000 \\
\hline $\mathrm{C}$ & -2.42299900 & -1.99608400 & 1.05876500 \\
\hline $\mathrm{H}$ & -3.02775200 & -2.88929600 & 0.83775700 \\
\hline $\mathrm{H}$ & -1.43652400 & -2.35111100 & 1.38890600 \\
\hline $\mathrm{H}$ & -2.88545100 & -1.50226700 & 1.92286800 \\
\hline $\mathrm{C}$ & -0.99740100 & 2.34533600 & 1.80248000 \\
\hline $\mathrm{H}$ & -1.26112500 & 2.70600000 & 2.80901200 \\
\hline $\mathrm{H}$ & 0.09694000 & 2.35113500 & 1.73287100 \\
\hline $\mathrm{H}$ & -1.36164200 & 3.09541700 & 1.08806900 \\
\hline $\mathrm{C}$ & 2.75290100 & 0.70263700 & 0.88964300 \\
\hline $\mathrm{H}$ & 2.59861000 & -0.37221300 & 0.95455600 \\
\hline $\mathrm{H}$ & 2.72133000 & 1.29706300 & 1.79734100 \\
\hline $\mathrm{C}$ & 2.94345200 & 1.39824000 & -0.37640400 \\
\hline
\end{tabular}




$\begin{array}{llll}\mathrm{H} & 3.66539700 & 2.21732500 & -0.35279500 \\ \mathrm{H} & 3.08814400 & 0.76483400 & -1.25371500 \\ \mathrm{O} & 1.61346400 & 1.95341800 & -0.28174700\end{array}$

IN1

$\begin{array}{lrrr}\mathrm{C} & -3.04209000 & 0.00086100 & 0.69431200 \\ \mathrm{H} & -3.05025000 & -0.88911700 & 1.34123500 \\ \mathrm{H} & -3.04928700 & 0.89398000 & 1.33689900 \\ \mathrm{C} & -1.79719400 & -0.00190200 & -0.17982300 \\ \mathrm{H} & -1.77987600 & 0.88204300 & -0.82028600 \\ \mathrm{H} & -1.78066600 & -0.88906200 & -0.81584400 \\ \mathrm{O} & -4.17189500 & -0.00066500 & -0.18213300 \\ \mathrm{H} & -4.98029400 & 0.00072600 & 0.35623500 \\ \mathrm{~N} & -0.56150400 & -0.00046700 & 0.63917900 \\ \mathrm{H} & -0.57766800 & 0.81139300 & 1.26188700 \\ \mathrm{H} & -0.57665700 & -0.81141800 & 1.26308800 \\ \mathrm{~B} & 0.91185500 & 0.00005000 & -0.14909100 \\ \mathrm{C} & 0.97186600 & 1.34807900 & -1.06987600 \\ \mathrm{H} & 1.95338500 & 1.36265300 & -1.57147900 \\ \mathrm{H} & 3.69287900 & -0.88120800 & 0.05142900 \\ \mathrm{C} & 0.24180000 & 1.28590300 & -1.89513700 \\ \mathrm{H} & 1.52530100 & 2.83665600 & 0.44360700 \\ \mathrm{H} & 3.45456800 & 0.00128600 & 0.66020800 \\ \mathrm{H} & 1.97983100 & 0.00065300 & 1.09201700 \\ \mathrm{H} & 1.81380100 & -0.87501500 & 1.74487100 \\ \mathrm{H} & 1.81301800 & 0.87617900 & 1.74487400 \\ \mathrm{H} & 0.97292100 & -1.34815200 & -1.06953500 \\ \mathrm{H} & 1.95426700 & -1.36204800 & -1.57151000 \\ \mathrm{H} & 0.24246900 & -1.28675800 & -1.89452100 \\ \mathrm{H} & 0.78048900 & 2.69419600 & -0.35068100 \\ \mathrm{H} & 0.86669000 & 3.55304700 & -1.03226000 \\ \mathrm{H} & -0.21074400 & 2.77060000 & 0.12204900 \\ \mathrm{H} & -0.00134100\end{array}$




$\begin{array}{lrrr}\mathrm{C} & 0.78297400 & -2.69424700 & -0.34992600 \\ \mathrm{H} & -0.20781600 & -2.77118400 & 0.12363300 \\ \mathrm{H} & 0.86920700 & -3.55317400 & -1.03140400 \\ \mathrm{H} & 1.52851700 & -2.83604000 & 0.44379700\end{array}$

\section{$\mathrm{AE}(\mathrm{EO})_{2}$}

\begin{tabular}{|c|c|c|c|}
\hline $\mathrm{C}$ & -2.95081400 & 0.43080700 & -0.04046200 \\
\hline $\mathrm{C}$ & -4.13563600 & -0.52623300 & -0.01957400 \\
\hline $\mathrm{O}$ & -1.75658600 & -0.33224500 & 0.00456300 \\
\hline $\mathrm{H}$ & -2.98528700 & 1.04793200 & -0.95104600 \\
\hline $\mathrm{H}$ & -2.99482300 & 1.11227800 & 0.82753100 \\
\hline $\mathrm{H}$ & -4.02430100 & -1.20968000 & 0.83787300 \\
\hline $\mathrm{C}$ & -0.58627600 & 0.46349500 & -0.03265600 \\
\hline $\mathrm{H}$ & -0.55746500 & 1.15449700 & 0.82481900 \\
\hline $\mathrm{H}$ & -0.55238100 & 1.06459000 & -0.95481900 \\
\hline $\mathrm{C}$ & 0.60868700 & -0.47423700 & 0.01862400 \\
\hline $\mathrm{H}$ & 0.58221700 & -1.16350200 & -0.83965900 \\
\hline $\mathrm{H}$ & 0.57485500 & -1.07594900 & 0.94022300 \\
\hline $\mathrm{O}$ & 1.78036800 & 0.32206400 & -0.01564400 \\
\hline $\mathrm{C}$ & 2.97260100 & -0.44227300 & 0.02529200 \\
\hline $\mathrm{H}$ & 3.01901900 & -1.04238800 & 0.94749000 \\
\hline $\mathrm{H}$ & 3.02347200 & -1.13073300 & -0.83267400 \\
\hline $\mathrm{C}$ & 4.14284000 & 0.52622600 & -0.01981900 \\
\hline $\mathrm{H}$ & 4.08452100 & 1.21042800 & 0.83832100 \\
\hline $\mathrm{H}$ & 4.09070400 & 1.11996700 & -0.94319900 \\
\hline $\mathrm{O}$ & 5.33261300 & -0.26251300 & 0.02442600 \\
\hline $\mathrm{H}$ & 6.10216400 & 0.32429000 & -0.00500600 \\
\hline $\mathrm{N}$ & -5.38361500 & 0.24563900 & -0.01936000 \\
\hline $\mathrm{H}$ & -6.18170200 & -0.35449800 & -0.21087400 \\
\hline $\mathrm{H}$ & -5.54536000 & 0.67548200 & 0.88956600 \\
\hline $\mathrm{H}$ & -4.10989100 & -1.13734000 & -0.92822400 \\
\hline
\end{tabular}

\section{HB1}

C

$\begin{array}{lll}3.03716700 & -0.86643800 & -0.08345600\end{array}$ 


\begin{tabular}{|c|c|c|c|}
\hline $\mathrm{C}$ & 4.27338400 & -0.07913500 & 0.31066900 \\
\hline $\mathrm{O}$ & 1.89390500 & -0.09249400 & 0.25959000 \\
\hline $\mathrm{N}$ & 4.35915300 & 1.14716800 & -0.48652600 \\
\hline $\mathrm{H}$ & 3.54144900 & 1.72635900 & -0.30542000 \\
\hline $\mathrm{H}$ & 3.04625600 & -1.05843600 & -1.16746900 \\
\hline $\mathrm{H}$ & 3.00942100 & -1.83176500 & 0.44795800 \\
\hline $\mathrm{H}$ & 4.24219700 & 0.09523800 & 1.40013700 \\
\hline $\mathrm{H}$ & 5.15584900 & -0.69501500 & 0.09851200 \\
\hline $\mathrm{H}$ & 5.18009700 & 1.69051600 & -0.22927600 \\
\hline $\mathrm{C}$ & 0.67433800 & -0.68304900 & -0.15132500 \\
\hline $\mathrm{H}$ & 0.54353100 & -1.67131700 & 0.31724300 \\
\hline $\mathrm{H}$ & 0.65697200 & -0.81833100 & -1.24379000 \\
\hline $\mathrm{C}$ & -0.45202500 & 0.24388400 & 0.27505100 \\
\hline $\mathrm{H}$ & -0.32433500 & 1.23126800 & -0.19575300 \\
\hline $\mathrm{H}$ & -0.43231500 & 0.38169300 & 1.36743500 \\
\hline $\mathrm{O}$ & -1.67259900 & -0.34908500 & -0.13196000 \\
\hline $\mathrm{C}$ & -2.80813600 & 0.42639600 & 0.21008900 \\
\hline $\mathrm{H}$ & -2.86827800 & 0.56871900 & 1.30042500 \\
\hline $\mathrm{H}$ & -2.75726600 & 1.42017200 & -0.26157500 \\
\hline $\mathrm{C}$ & -4.03905900 & -0.31635700 & -0.28233900 \\
\hline $\mathrm{H}$ & -4.08205100 & -1.30727000 & 0.19114200 \\
\hline $\mathrm{H}$ & -3.97279300 & -0.45268700 & -1.37086000 \\
\hline $\mathrm{O}$ & -5.17013000 & 0.47938000 & 0.07402500 \\
\hline $\mathrm{H}$ & -5.97623500 & 0.03647100 & -0.22839400 \\
\hline
\end{tabular}

\section{$\mathrm{AH}(\mathrm{EO})_{2}$}

$\begin{array}{crrr}\mathrm{C} & 0.47014600 & -0.54393600 & -0.01255200 \\ \mathrm{H} & 0.47259500 & -1.22218800 & 0.85672400 \\ \mathrm{H} & 0.46952100 & -1.16827900 & -0.92127200 \\ \mathrm{C} & 1.69290000 & 0.35898100 & 0.01246900 \\ \mathrm{H} & 1.65095800 & 1.03871600 & -0.84955400 \\ \mathrm{H} & 1.65646200 & 0.98298900 & 0.91594000 \\ \mathrm{C} & 3.00235000 & -0.43663800 & -0.01715400 \\ \mathrm{H} & 3.02730600 & -1.06684400 & -0.91823900\end{array}$




\begin{tabular}{|c|c|c|c|}
\hline $\mathrm{H}$ & 3.03358000 & -1.12229500 & 0.84249600 \\
\hline $\mathrm{C}$ & 4.24647600 & 0.45762100 & 0.00625100 \\
\hline $\mathrm{H}$ & 4.22109100 & 1.08909400 & 0.90660000 \\
\hline $\mathrm{H}$ & 4.21529100 & 1.14246700 & -0.85413700 \\
\hline $\mathrm{C}$ & 5.55688900 & -0.33491600 & -0.02501400 \\
\hline $\mathrm{H}$ & 5.58620600 & -0.97123200 & -0.92051700 \\
\hline $\mathrm{H}$ & 5.59478300 & -1.01122100 & 0.84284600 \\
\hline $\mathrm{C}$ & 6.79618300 & 0.55821400 & -0.01477600 \\
\hline $\mathrm{H}$ & 6.75662100 & 1.22188000 & 0.86629200 \\
\hline $\mathrm{H}$ & 6.78975600 & 1.20387300 & -0.90210700 \\
\hline $\mathrm{N}$ & 8.02739500 & -0.25000600 & -0.06061100 \\
\hline $\mathrm{H}$ & 8.84416800 & 0.36044900 & -0.07222000 \\
\hline $\mathrm{H}$ & 8.10374200 & -0.80478600 & 0.79274700 \\
\hline $\mathrm{O}$ & -0.70774900 & 0.25907600 & 0.01376700 \\
\hline $\mathrm{C}$ & -1.89698100 & -0.51356900 & -0.01014700 \\
\hline $\mathrm{H}$ & -1.93871300 & -1.18565300 & 0.86170200 \\
\hline $\mathrm{H}$ & -1.93672200 & -1.13341800 & -0.91991700 \\
\hline $\mathrm{C}$ & -3.07397500 & 0.44663400 & 0.01647400 \\
\hline $\mathrm{H}$ & -3.03703600 & 1.06599500 & 0.92598600 \\
\hline $\mathrm{H}$ & -3.03541600 & 1.11701900 & -0.85602900 \\
\hline $\mathrm{C}$ & -5.43804400 & 0.47297300 & 0.01287500 \\
\hline $\mathrm{H}$ & -5.46357100 & 1.09497200 & 0.92123300 \\
\hline $\mathrm{H}$ & -5.46096600 & 1.14242000 & -0.86117600 \\
\hline $\mathrm{C}$ & -6.63642800 & -0.45954600 & -0.01371100 \\
\hline $\mathrm{H}$ & -6.60929700 & -1.12439700 & 0.86068100 \\
\hline $\mathrm{H}$ & -6.60698100 & -1.07659300 & -0.92237600 \\
\hline $\mathrm{O}$ & -4.26511900 & -0.32743400 & -0.00678900 \\
\hline $\mathrm{O}$ & -7.80887100 & 0.36305300 & 0.00685400 \\
\hline $\mathrm{H}$ & -8.58832800 & -0.21538900 & -0.01036800 \\
\hline
\end{tabular}

\section{HB2}
C
$\begin{array}{lll}0.93330100 & 1.64072100 & -0.64858100\end{array}$
C
$\begin{array}{lll}2.21054500 & 2.22431100 & -0.05810400\end{array}$
C
$3.96733400 \quad-1.78942400 \quad-0.46537600$ 


\begin{tabular}{|c|c|c|c|}
\hline $\mathrm{C}$ & 3.44168900 & 1.31187400 & -0.20192500 \\
\hline $\mathrm{C}$ & 4.50923100 & -0.88078900 & 0.65489600 \\
\hline $\mathrm{C}$ & 3.61612700 & 0.32822900 & 0.96787200 \\
\hline $\mathrm{H}$ & 1.06413700 & 1.46770300 & -1.72905700 \\
\hline $\mathrm{H}$ & 2.04560800 & 2.47599400 & 0.99897400 \\
\hline $\mathrm{H}$ & 3.35462400 & 0.76582200 & -1.15049900 \\
\hline $\mathrm{H}$ & 4.03710100 & -1.27687900 & -1.43190800 \\
\hline $\mathrm{H}$ & 5.51899500 & -0.54469300 & 0.37282100 \\
\hline $\mathrm{H}$ & 0.10427800 & 2.35092000 & -0.52038500 \\
\hline $\mathrm{H}$ & 2.38096800 & 3.17421500 & -0.58269600 \\
\hline $\mathrm{H}$ & 4.60382800 & -2.67995700 & -0.54198100 \\
\hline $\mathrm{H}$ & 4.34993500 & 1.92360700 & -0.28842900 \\
\hline $\mathrm{H}$ & 4.62323500 & -1.48064700 & 1.57009200 \\
\hline $\mathrm{H}$ & 4.03303900 & 0.87119000 & 1.82773100 \\
\hline $\mathrm{H}$ & 2.63133400 & -0.02928700 & 1.28648900 \\
\hline $\mathrm{N}$ & 2.57418700 & -2.23820700 & -0.30989600 \\
\hline $\mathrm{H}$ & 2.46701100 & -2.72089400 & 0.58318900 \\
\hline $\mathrm{H}$ & 1.95715100 & -1.42547500 & -0.26498700 \\
\hline $\mathrm{O}$ & 0.61307600 & 0.39235200 & -0.02168600 \\
\hline $\mathrm{C}$ & -0.59945700 & -0.19260100 & -0.48752400 \\
\hline $\mathrm{H}$ & -0.71323500 & -0.03535500 & -1.56988900 \\
\hline $\mathrm{H}$ & -0.52011900 & -1.26981600 & -0.30676600 \\
\hline $\mathrm{C}$ & -1.81005100 & 0.35995000 & 0.25809500 \\
\hline $\mathrm{H}$ & -1.89911200 & 1.44772000 & 0.11657500 \\
\hline $\mathrm{H}$ & -1.70287600 & 0.16412900 & 1.33637400 \\
\hline $\mathrm{C}$ & -4.16145100 & 0.13045000 & 0.38383200 \\
\hline $\mathrm{H}$ & -4.30921300 & 1.21253800 & 0.24185400 \\
\hline $\mathrm{H}$ & -4.11304000 & -0.06942600 & 1.46558400 \\
\hline $\mathrm{C}$ & -5.31466900 & -0.63868600 & -0.23651100 \\
\hline $\mathrm{H}$ & -5.16402900 & -1.71702400 & -0.08909300 \\
\hline $\mathrm{H}$ & -5.35850500 & -0.43680800 & -1.31568200 \\
\hline $\mathrm{O}$ & -2.96431200 & -0.29348000 & -0.25219700 \\
\hline $\mathrm{O}$ & -6.51170900 & -0.19669700 & 0.41454400 \\
\hline $\mathrm{H}$ & -7.26245100 & -0.68174900 & 0.03563000 \\
\hline
\end{tabular}

